\title{
Influence of temperature and macrophytes development on the lar- val population dynamics of Epeorus sylvicola Pict (Ephemeroptera) in a torrential river of the «Haut-Atlas de Marrakech» (Morocco)
}

\author{
H. Ouahsine ${ }^{1}$ \\ R. Céréghino ${ }^{2}$ \\ P. Lavandier ${ }^{2}$
}

Keywords : Insect, life cycle, production.

Two successive generations of Epeorus sylvicola were studied in the Tifferguine, a torrential river in Morocco (2600 $\mathrm{m}$ altitude, water temperature $0-22^{\circ} \mathrm{C}$, snow-cover : 1-2 months/year).

The life cycle took one year and larval growth depended on temperature. Larvae fed on periphyton and lived mainly on stony substrates. In spring, macrophytes overgrew the bottom river and markedly reduced the amount of non-vegetated area ; combined with maximum and potentially lethal temperatures $E$. sylvicola larvae disappeared in May. Consequently, annual production depended on the development stage reached by the cohort when such unfavourable conditions occurred.

Influence de la température et du développement des macrophytes sur la dynamique des populations larvaires de Epeorus sylvicola Pict (Ephemeroptera) dans un torrent du Haut-Ätlas de Marrakech (Maroc)

Mots clés : Insecte, cycle biologique, production.

Deux générations successives d'Epeorus sylvicola ont été étudiées dans un torrent de haute montagne : le Tifferguine (altitude $2600 \mathrm{~m}$; température $0-22 \mathrm{C}^{\circ}$; couvert de neige $1-2$ mois par an).

Le cycle biologique dure un an. La vitesse de croissance dépend de la température. Les larves se nourrissent de périphyton et occupent principalement les substrats pierreux. Au printemps, les végétaux qui envahissent le lit et réduisent la surface d'habitat de l'espèce provoquent (associés à des températures maximum devenant léthales ?) la disparition des larves en mai. Ainsi chaque année, la production dépend du degré de développement atteint par la cohorte quand surviennent ces conditions défavorables.

\section{Introduction}

Epeorus sylvicola is an Ephemeroptera widely distributed in Europe and in the moutain streams of North Africa (Bouzidi \& Giudicelli 1994). However there are no precise quantitative data on its population dynamics. E. sylvicola seems to be a univoltine species in Central Europe (Landa 1968) as it is in some rivers of Sierra Nevada, Spain (Alba-Tercedor 1990).

The aims of the present study were 1) to give the first quantitative account of the life cycle of E. sylvicola and 2) to determine the influence of conditions on the life cycle and production of $E$. sylvicola in a high mountain stream of Morocco, which presents the classic varia-

1. Université Cadi Ayyad, Faculté des Sciences, boulevard de Safi, B.P. 515, Marrakech, Maroc.

2. CESAC, Laboratoire d'Hydrobiologie, U.M.R. C 5576, Université Paul Sabatier, 118, route de Narbonne, 31062 Toulouse Cedex, France. tions in temperature and discharge as well as intensive seasonal macrophyte cover. Larval density, growth, mortality and production over a two year period are examined in relation to the environmental conditions.

\section{Study area}

The Assif Tifferguine is a permanent torrential river that lies in a chiefly cristallin basin in the «Haut Atlas de Marrakech» in Morocco. It is 2,5 km long, rising at $2700 \mathrm{~m}$ a.s.l. and ending at $2500 \mathrm{~m}$ where it joins the River Oukaimeden. The sampling site was located $1 \mathrm{~km}$ from the source at $2600 \mathrm{~m}$ a.s.l..

During the study (July 1985 - May 1987), the catchment area was covered with snow 4-5 months per year, snow -cover and snow-melt flood being greater and lasting longer in 1986 than in 1987. River discharge fluctuated according to rain fall and snow melt, being lower than $20 \mathrm{l} \mathrm{s}^{-1}$ at the beginning of winter and exceeding $2501 \mathrm{~s}^{-1}$ in spring (Pihan \& Mohati 1983). 
Water velocity ranged from 2 to $30 \mathrm{~cm} \mathrm{~s}^{-1}$ at low discharge and 20 to $150 \mathrm{~cm} \mathrm{~s}^{-1}$ during the floods.

Near the source, the manure from a sheepfold is spread out along and in the stream, causing increased macrophyte growth. Thus, every spring the stony stream bed was progressively overgrown by Ranunculus aquaticus and Roriparia nasturtium, which enhanced the sedimentation of fine vegetable debris and mineral particles. Fragments of vegetation were permanently stripped by the current, mainly in September and October, when the vegetation completed its vegetative cycle. The mean width of the stream changed according to the variations of discharge and to the macrophytes extension which reduced the stream flow ; it was estimated at every sampling date (Fig. 1).

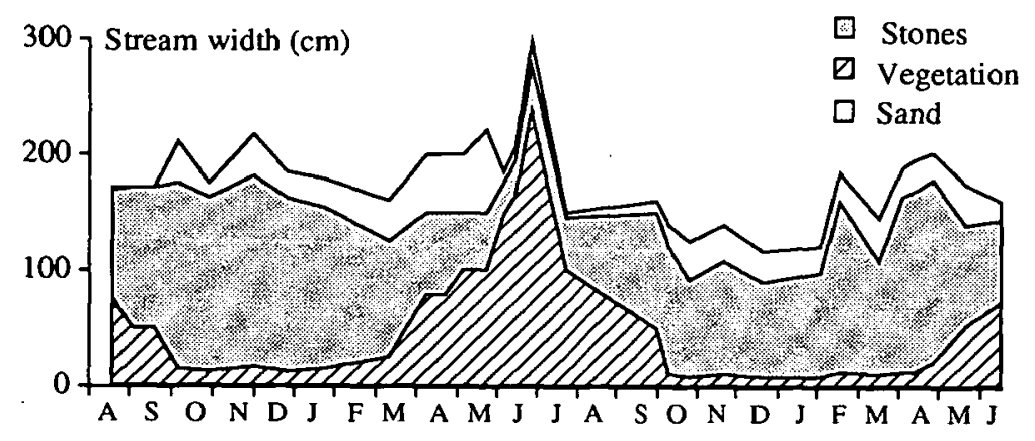

Fig. 1. Changes in the river width and in the area of the three main kinds of substrate (macrophytes, sand, stones) during the study.

Fig. 1. Évolution de la largeur du torrent et de la surface des trois principaux types de substrat (macrophytes, sable, pierres) au cours de l'étude.

Several instantaneous measures of temperature were taken around midday on each sampling date (their values were close to the daily maximum temperatures) as well as over a $24 \mathrm{~h}$ period in July 1986 . Weekly maximum and minimum temperatures were recorded from $24^{\text {th }}$ December 1985 to $24^{\text {th }}$ June 1986 and from $10^{\text {th }}$ April 1987 to $13^{\text {th }}$ June 1987 . These observed river temperature values were subject to correlation analysis with air temperatures which were recorded continuously at the neighbouring meteorological station of Oukaimeden, to estimate a monthly mean water temperature (Fig. 2).

\section{Material and methods}

The bottom samples were collected from July 1985 to September 1987 using a surber sampler (sampling area $0,1 \mathrm{~m}^{2}$, aperture $0,30 \mathrm{~mm}$ ). Five to six samples

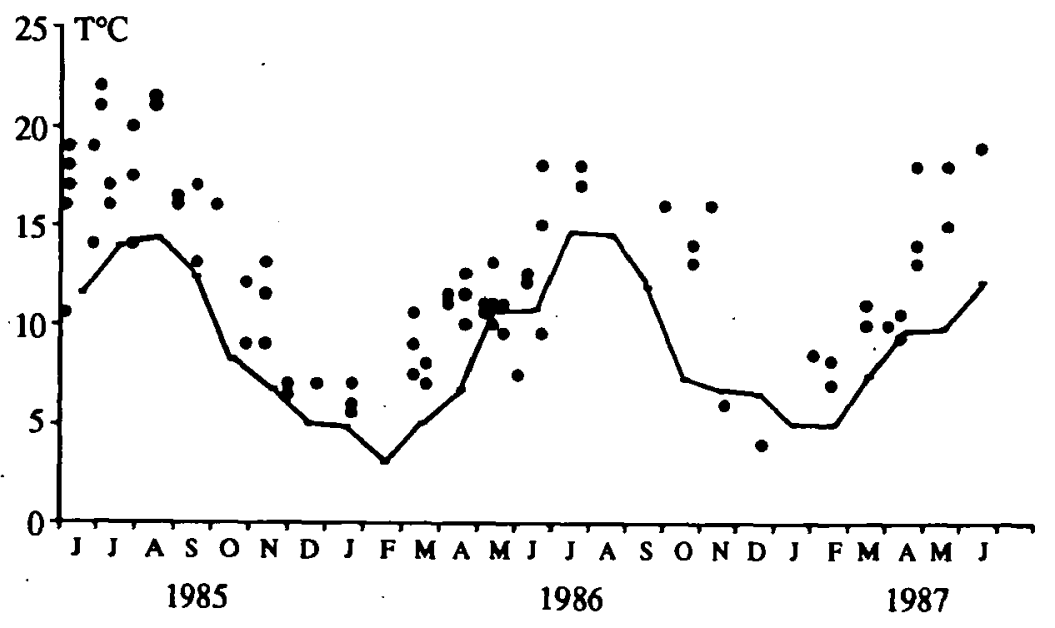

Fig. 2. Instantaneous temperatures measured at each sampling period (solid circles) and estimated mean monthly temperatures (line, see text).

Fig. 2. Valeurs instantanées de la température de l'eau relevées aux différentes dates d'échantillonnage (points) et températures moyennes mensuelles estimées (ligne, cf. texte).

were taken in the various kinds of substrates every three four weeks according to the season. The samples were preserved in $5 \%$ formalin in the field. The fauna were hand-sorted in the laboratory and preserved in $70 \%$ alcohol. Adults were caught using a sweep net.

Larval density, biomass, production and diet were determined from measurements using head width (hw) as the size criterium. The mean length and dry weight $\left(65^{\circ} \mathrm{C}\right.$ for $\left.24 \mathrm{~h}\right)$ of the larvae in every size class were calculated from the following relationships :

Ln length $(\mathrm{mm})=1,48 \mathrm{ln} \mathrm{hw}+1,13$.

Ln dry weight (mg) $=4,32$ ln hw $-1,79$.

For each sampling period, the individual weight of the larvae was calculated from the biomass in each size class. The mean biomass of a cohort was calculated as the sum of the monthly mean biomasses divided by the number of months during which the larvae were present in the river.

The number of larvae at each sampling date was estimated by taking into account the density observed in every kind of substrate and the respective areas of the different substrates in the river. To make these estimations independent of changes in the width of the stream, they were expressed with respect to an invariable width (Lavandier 1992). The annual production of $E$. sylvicola larvae was estimated by Allen's graphical method (1951).

Diet was determined from the intestinal contents of about 15 larvae; the food was spread out on a glass slide and analysed under a microscope. 


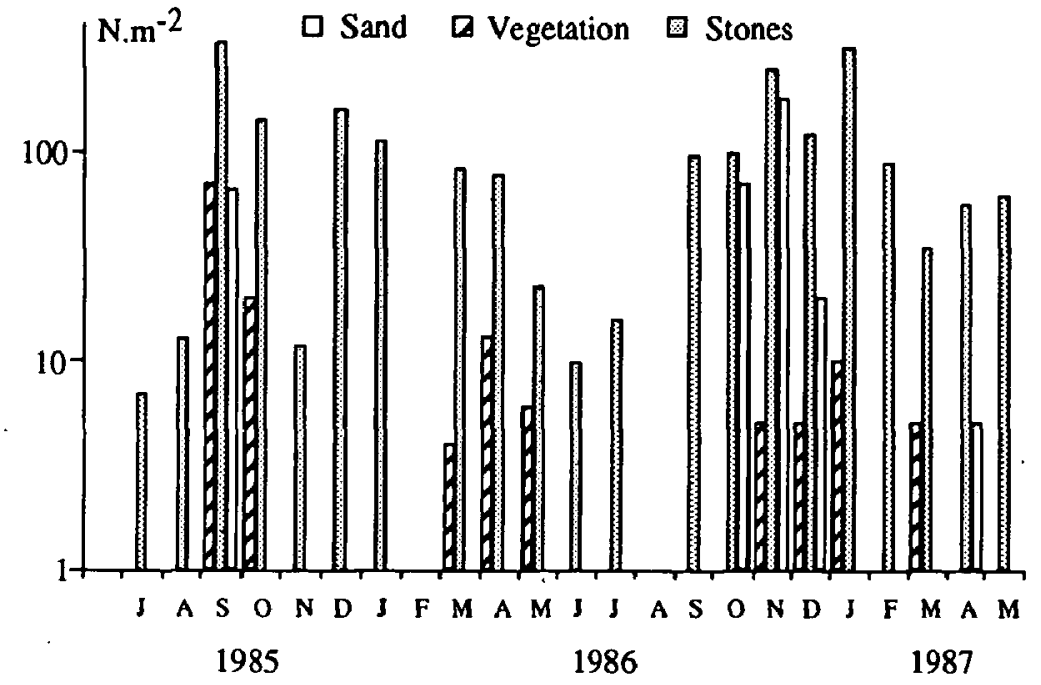

Fig. 3. Spacial distribution of Epeorus sylvicola. Numbers of larvae $\mathrm{m}^{-2}$ in the three main kinds of substrate (macrophytes, sand, stones) during the study.

Fig. 3. Distribution spaciale de Epeorus sylvicola. Nombre de larves $\mathrm{m}^{-2}$ dans les trois principaux types de substrat (macrophytes, sable, pierres).

\section{Results}

Regardless of the larval size, E. sylvicola were distributed mainly on the stony bottom, even though the new hatched larvae can be caught on the various kinds of substrate (Fig. 3). Older larvae almost lived exclusively on pebbles and gravel in moderated to fast currents. Thus, the expension of macrophytes during the spring dramatically reduced the amount of suitable free substrate for the species.

E. sylvicola is a «scraper» (Cummins 1973) feeding chiefly on periphyton (diatoms and cyanophytes). These algae were generally mixed with fine mineral particles in the gut contents.

The larval development patterns were deduced from the population structure at the various sampling periods (Fig. 4a). Newly hatched larvae were mainly caught in August and September ; in 1986, some larvae were found in July. The initial development of larvae was fast, and numerous classes of size were observed at the end of the year. In winter, population structure changed more slowly. The development resumed in spring and the flight period, deduced from the occurrence of subimagines and mature larvae ready to emerge, extended over April and May. Emergence was slightly earlier in 1987 than in 1986. E. sylvicola is clearly univoltine, with hatching and emergence periods rather short. Paradoxically a large range of larval sizes were always present in the river.
Increases in the mean individual weight of the larvae showed three successive phases, corresponding to the three phases of the life cycle and there was a significant relationship $(P=0,05)$ between the time and the logarithm of the weight of the larvae (Fig. 4b) except during winter. During the initial period of the life cycle, instantaneous growth rates in weight (expressed as \% dry weight per day) were high : $4.36 \pm 1.4 \%$ $(n=4)$ from August to November in 1986 and $3.72 \pm$ $1 \%(n=5)$ from July to December in 1987. In winter, growth slowed and the rates were about $0.6-0.7 \%$; the low growth period was larger for the 1986 generation (from November to March) than for the following one (from December to February). The growth rate increased until the beginning of the flight period $2.4(n=3)$ and $1.8 \pm 2 \%(n=4)$ respectively for the two successive cohorts). There was a significant relationship between instantaneous growth rates and mean water temperature (Fig. 5).

The highest population densities occurred in September at the end of the egg hatching period and were very similar for the two studied years : 188 et 196 larvae $\mathrm{m}^{-2}$ in 1986 and 1987 respectively. Then, the numbers of the two generations decreased exponentially with time until May : $1 \pm 0.07 \%$ day $^{-1}(n=8)$ in 1986 , and $1.2+0.2 \%$ day $^{-1}(n=10)$ in 1987 . Less than $10 \%$ of the maximum number of larvae caught in September survived to the beginning of the flight period, and the last larvae disappeared during the month of May.

For the two 1985 and 1986 year-classes, the most important biomasses were observed at the beginning of winter (55-80 mg dry weight $\mathrm{m}^{-2}$ ) and just before the first emergences (65-75 $\mathrm{mg}$ dry weight $\mathrm{m}^{-2}$ ). The annual mean biomass of larvae was estimated as 21 and $36 \mathrm{mg}$ dry weight $\mathrm{m}^{-2}$. The production of the cohorts was 110 and $209 \mathrm{mg} \mathrm{m}^{-2}$ respectively. The year-toyear variations in biomass and production depended mainly on the number of old larvae caught in the second part of the life cycle.

\section{Discussion}

This paper is the first quantitative account on the larval life of E. sylvicola. In the Tifferguine, E. sylvicola is a «winter» univoltine species, which grows mainly during autumn and spring as it does in several mountain streams in Sierra Nevada (Spain) (Alba-Tercedor 1990) and in Central Europe (Landa 1968). Univoltinism seems to be a characteristic of Epeorus species (Alba-Tercedor 1990, Landa 1968, Flowers \& Hilsenhoff 1978, Lehmkuhl 1968, Minshall 1967) even though E. torrentis can be partly bivoltine (Thibault 1971). 

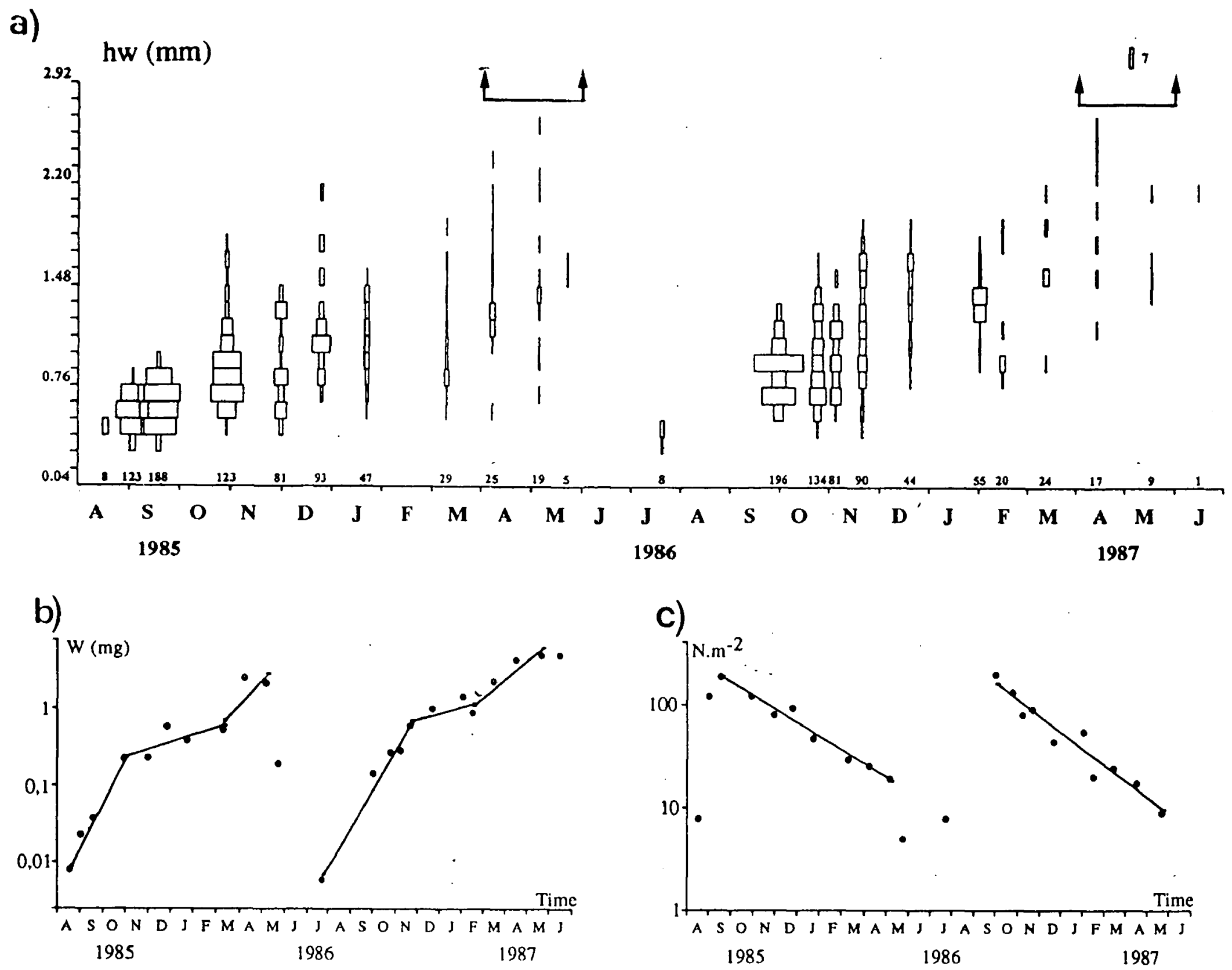

Fig. 4. Life cycle of Epeorus sylvicola. Size frequency distribution of the larvae (a). Mean individual weight of the larvae (b) and numbers of larvae caught at each sampling period (c). hw = head width in $\mathrm{mm}, \mathrm{W}=\mathrm{dry}$ weight in $\mathrm{mg}, \mathrm{N}=$ numbers $\mathrm{m}^{-2}$. The arrows indicate the approximative times of emergence.

Fig. 4. Cycle biologique de E. sylvicola. Structure des populations larvaires (a). Poids individuel moyen des larves (b) et nombre de larves capturées à chaque date d'échantillonnage (c). $\mathrm{hw}=$ largeur des capsules céphaliques en $\mathrm{mm}, \mathrm{W}=$ poids sec en $\mathrm{mg}, \mathrm{N}=$ effectif $^{-2}$. Les flèches indiquent les périodes approximatives d'émergence.

In the Tifferguine, the mortality of E. sylvicola larvae was constant during the larval life though growth clearly decreased during winter. The fact that growth rates depend on temperature is a usual observation that has already been proved true for several ephemeroptera species in the Tifferguine (Ouashine \& Lavandier 1988, 1996).

Similar development patterns were observed during the two studied years especially the maximum number of the larvae at the beginning of the life cycle and the growth and mortality rates which showed no significant differences between the two successive genera- tions. However, the development of the various life cycle steps varied from year to year. Larval growth decreased less in winter than that of the following generation hatched in 1986. As a result, the 1985 year-class larvae showed a large range of sizes already coexisting in the river in spring, whereas the following year most of the 1986 year-class larvae had achieved their development at the same time.

During the two years of study, larvae completely disappeared in May regardless of their size. Besides emergence, these losses could be due to : 1) water temperatures, which would become too high and lethal for 


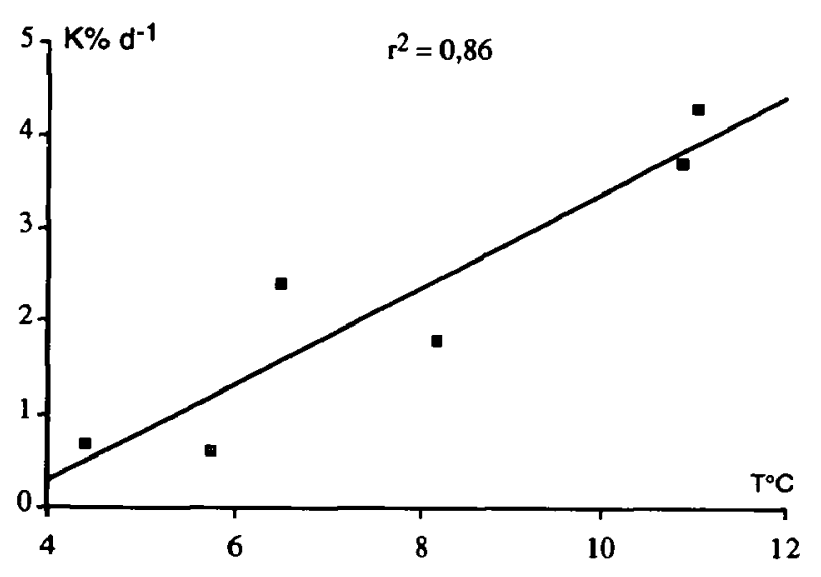

Fig. 5. Relationship between specific growth rate $(\mathrm{K}=\%$ weight $\mathrm{day}^{-1}$ ) of Epeorus sylvicola and the mean water temperature $\left(\mathrm{T}^{\circ} \mathrm{C}\right)$.

Fig. 5. Relation entre le taux de croissance spécifique ( $\mathrm{K}=\%$ poids jour $\left.^{-1}\right)$ d'E$^{\prime}$. sylvicola et la température moyenne de l'eau $\left(\mathrm{T}^{\circ} \mathrm{C}\right)$.

the older larvae. Indeed, only very rare old larvae of $E$. torrentis and/or E. sylvicola have been found in the rivers of Sierra Nevada when water temperature exceeded $15-16^{\circ} \mathrm{C}$ (Alba-Tercedor 1990). Similarly, several American species of Epeorus could not withstand temperatures above $16^{\circ} \mathrm{C}$ (Ide 1935, Lehmkuhl 1968);2) aquatic macrophytes, which colonized the stream bed and reduced the amount of free stony substrates which are the only milieu in which. E. sylvicola lived. Consequently, the number of larvae achieving their growth and the larval production depended every year on the development stage reached by the cohort when these unfavorable conditions occurred. This is analogous in part to what happens in temporary waters. However, the fact that the density of the young larvae in these two successive generations was similar suggests that the year-to-year variations in adult production at the site probably has no effect on the density of the species: the number of adults - which can be enhanced by the well known upstream migration of ephemeroptera female adults in mountain rivers (Lavandier 1981, 1982) - is probably sufficient to generate a new population whose density exceeds the carrying capacity of the river every year.

\section{Acknowledgments}

We thank Dr. Gordon Copp for his valuable comments and for improving the English text and J. Brabet for her technical assistance.

\section{References}

Alba -Tercedor J. 1990. - Life cycle and ecology of mayflies from Sierra Nevada (Spain), IV. Limnética, 6 : 23-24.

Allen J.D. 1951. - The Horokiwi stream. A study of a trout population. Fish. Bull. N.Z., $10: 1-231$.

Bouzidi A. \& Giudicelli J. 1994. - Ecologie et distribution spaciale des macroinvertébrés des eaux courantes du Haut Atlas Marocain. Rev. Fac. Sci. Marseille, 8 : 23-43.

Clifford H.F. 1982. - Life cycles of mayflies (Ephemeroptera) with special reference to voltinism. Quaest. Entomol., 18 : 15-89.

Cummins K.W. 1973. - Trophic relations of aquatic insects. Ann. Rev. Entomol., 18 : 183-206.

Flowers R.W. \& Hilsenhoff W.L. 1978. - Life cycles and habitats of Wisconsin Heptageniidae (Ephemeroptera). Hydrobiologia, $60: 159-171$.

Hartland-Rowe R. 1964. - Factors influencing the life-histories of some stream insects in Alberta. Verh. Internat. Verein. Limnol., XV : 917-925.

Ide F.D. 1935. - The effect of temperature on the distribution of the mayfly fauna of a stream. Publ. Ontario Fish. Research Lab., $50: 3-73$.

Landa V. 1968. - Developmental cycles of central european ephemeroptera and their interrelations. Acta ent. bohemoslov., 65 : 276-284.

Lavandier P. 1981. - Cycle biologique, croissance et production de Rhithrogena loyolaea Navas (Ephemeroptera) dans un torrent pyrénéen de haute montagne. Annls Limnol., 17 (2) : 163-171.

Lavandier P. 1982. - Evidence of upstream migration by female adults of Baetis alpinus Pict. (Ephemeroptera) at high altitude in the Pyrénées. Annls Limnol., 18 (1) : 55-59.

Lavandier P. 1992. - Larval production and drift of Drusus discolor (Trichoptera, Limnephilidae) in a high mountain stream in the Pyrénées (France). Arch. Hydrobiol., 125: 83-96.

Lehmkuhl D.M. 1968. - Observations on the Life Histories of Four Species of Epeorus in Western Oregon (Ephemeroptera : Heptageniidae). The Pan-Pacific Entomologist, 44 : 129-137.

Minshall J.N. 1967. - Life history and ecology of Epeorus pleuralis (Bank)) (Ephemeroptera : Heptageniidae). Am. Midl. Nat., $78: 369-388$.

Ouashsine H. \& Lavandier P. 1988. - Dynamique des populations larvaires de Baetis navasi M.-L. (Ephemeroptera) dans un torrent du Haut-Atlas de Marrakech, Maroc : Annls Limnol., 24 : 167-171.

Ouahsine H. \& Lavandier P. 1996. - Cycle biologique et croissance larvaire de six espèces d'éphéméroptères dans un torrent du Haut-Atlas de Marrakech, Maroc. Hydroécol. Appl. (sous presse).

Pihan J.C. \& Mohati A.. 1983. - Étude hydrobiologique de deux petits torrents du Haut-Atlas de Marrakech. Bull. Fac. Sci, Marrakech, 2 : 23-42.

Thibault M. 1971. — Le développement des éphéméroptères d'un ruisseau à truites des Pyrénées-Atlantiques, le Lissuraga. Annls Limnol., 7 : 53-120. 